\title{
PENGEMBANGAN BAHAN AJAR CETAK BERBASIS PENDEKATAN PROBLEM SOLVING UNTUK MENINGKATKAN LITERASI MATEMATIS
}

\author{
(DEVELOPMENT OF PRINTED TEACHING MATERIALS \\ BASED ON THE PROBLEM SOLVING APPROACH TO IMPROVE \\ MATHEMATIC LITERATION)
}

\author{
Huswatun Hasanah ${ }^{1}$ \\ ${ }^{1}$ Universitas Banten Jaya, huswatunhasanah2016@gmail.com
}

\begin{abstract}
Abstrak
Penelitian ini bertujuan untuk mengetahui karakteristik bahan ajar cetak yang memadai bagi peningkatan kemampuan literasi matematis siswa menggunakan pendekatan problem solving. Penelitian pengembangan ini melalui proses yang cukup panjang, yaitu pembuatan desain awal bahan ajar, pengujian ahli, revisi sesuai saran dan kritik para ahli, pengujian skala terbatas, serta revisi sesuai hasil uji skala terbatas. Uji skala terbatas dilakukan pada siswa kelas VIII SMP. Data penelitian diperoleh dengan menggunakan metode angket. Pengolahan data angket menggunakan skala likert. Kesimpulan yang diperoleh dalam penelitian ini adalah hasil dari analisis pengujian para ahli bahwa bahan ajar berbasis pendekatan problem solving dapat meningkatkan kemampuan literasi matematis siswa dan menunjukan hasil yang baik dengan masing-masing perolehan skor untuk uji ahli matematika sebesar $81,5 \%$, uji ahli pendidikan $82,67 \%$, uji ahli desain $74,29 \%$, dan uji coba skala terbatas sebesar $83 \%$.
\end{abstract}

Kata kunci: Bahan Ajar Cetak, Pendekatan Problem Solving, Literasi Matematis.

\begin{abstract}
The study aims to find out the characteristics of the appropriate book for improving literacy ability of students using problem solving approach. The development research through a long process, which is making preliminary design instructional materials, testing experts, the revision of the advice and criticism of experts, testing on a limited scale, as well as revised in accordance limited scale test results. Limited scale test conducted in class VIII SMP. Data were obtained by using questionnaires. Data processing uses a Likert scale questionnaire. The conclusion of this research is the result of the analysis of testing experts that the teaching material based on problem solving approach can improve students' mathematical literacy skill and can show a good results with their respective test scores for the acquisition of a mathematician by 81,5\%, education experts test 82, 67\%, design experts test $74,29 \%$, and the limited scale trial by $83 \%$.
\end{abstract}

Keywords: Printed Instructional Materials, Problem Solving Approach, Mathematical Literacy.

\section{PENDAHULUAN}

Pada abad 21 setiap bangsa dihadapkan pada tuntutan akan pentingnya sumber daya manusia yang berkualitas serta mampu berkompetisi. Hal ini membuat manusia harus bisa menguasai keterampilan dan kemampuan yang dibutuhkannya untuk memahami dan menyelesaikan permasalahan di dalam 
kehidupan yang selalu berkembang setiap saat. Matematika sering dipandang sebagai alat bantu manusia untuk menyelesaikan permasalahan kehidupan. Matematika penting karena matematika memberi peluang berkembangnya kemampuan menalar siswa untuk berpikir logis, sistematik, kritis dan cermat, kreatif, menumbuhkan rasa percaya diri, serta mengembangkan sikap obyektif dan terbuka yang sangat diperlukan dalam menghadapi masa depan yang selalu berubah.

Pengambil kebijakan pendidikan di Indonesia telah mengambil langkah untuk mengevaluasi hasil pendidikan matematika kita dengan menyandingkan di antara negara-negara lain. Sejak awal tahun 2000 Indonesia telah mengikuti Programme for International Student Assesment (PISA) dan Trends in International Mathemathics and Science Study (TIMSS). Hasil survey PISA 2012 menunjukkan Indonesia menempati peringkat ke-64 dari 65 negara pada kategori literasi matematis. Sementara itu, menurut penelitian TIMSS tahun 2011 menunjukan bahwa Indonesia berada di peringkat ke-38 dari 42 negara peserta dengan skor rata-rata 386, sedangkan skor rata-rata internasional 500.

Penyebab utama performa siswa-siswa tersebut buruk dalam matematika adalah seringnya mereka salah dalam pemahaman konsep matematika. Menurut Pranoto seharusnya peran matematika tidak saja sebagai sarana untuk menghitung secara cepat dan tepat, tetapi justru agar siswa mampu menyelesaikan masalah matematika dengan menguasai siklus pematematikaan utuh, yaitu mematematikakan masalah nyata menjadi masalah matematika - menyelesaikan masalah matematika - menafsirkan solusi matematika ke situasi semula/ nyata. Kilpatrick menyatakan seharusnya pembelajaran matematika di sekolah harus memperhatikan kompetensi yang sesuai dengan perkembangan zaman sehingga menjadi wadah untuk mengembangkan komponen-komponen yang merangkum apa yang seharusnya dikuasai agar mereka berhasil dalam belajar matematika.

Literasi matematis (mathematical literacy) meliputi kemampuan mengidentifikasi (identify) dan memahami (understanding), menggunakan dasardasar matematika dalam kehidupan, yang diperlukan seseorang dalam menghadapi kehidupan sehari-hari. Hal ini berarti bahwa literasi matematis adalah kemampuan untuk mengetahui konsep dasar dan teknik serta prinsip matematika yang berfungsi untuk memperkirakan sebuah solusi dari masalah dunia nyata. Proporsi siswa Indonesia yang memiliki literasi matematis rendah (di bawah level 2) itu mencapai 76, 6\%. Dampaknya kalau ini dibiarkan, bangsa Indonesia akan menghadapi masa depan yang suram.

Dengan demikian, seharusnya Indonesia menyiapkan solusi dalam pembelajaran matematika. Pembelajaran matematika yang memperhatikan literasi matematis sanggup untuk menampilkan tujuan sebenarnya dari pembelajaran matematika dan juga mengembangkan komponen-komponen yang merangkum apa yang seharusnya dikuasai agar mereka berhasil dalam belajar matematika. Sampai saat ini, pembelajaran matematika masih bersifat tradisional, yaitu pembelajaran berpusat pada guru, pendekatan yang digunakan bersifat ekspositori, guru lebih banyak mendominasi aktivitas kelas, latihan-latihan yang digunakan lebih banyak rutin, serta dalam proses belajar mengajar siswa menjadi pasif. Pada pembelajaran konvensional yang sering digunakan, guru biasanya mengajar dengan berpedoman pada buku teks atau Lembar Kerja Siswa (LKS) dengan menggunakan metode ceramah atau ekspositori dan terkadang tanya jawab. Hal 
ini disebabkan kurangnya kreativitas guru untuk mengembangkan metode pembelajaran atau kurangnya waktu yang disediakan agar pembelajaran lebih interaktif. Oleh karena metode guru matematika sering menggunakan buku teks atau LKS yang kurang memfasilitasi soal-soal yang meningkatkan kemampuan literasi matematis siswa, maka diperlukan adanya bahan ajar atau LKS yang melatih siswa untuk memiliki kemampuan literasi matematis siswa. Bahan ajar ini bersifat terbuka pada kehidupan sehari-hari, memiliki karakter soal yang bisa menimbulkan kemampuan problem solving siswa dan mengarah kepada investigasi, tidak semata-mata persoalan matematika yang jauh dari kehidupan sehari-hari. Dengan mengembangkan bahan ajar yang telah ada menjadi bahan ajar yang memiliki karakter soal berbasis problem solving serta tidak jauh dengan soal yang diberikan dalam PISA diharapkan mampu meningkatkan kemampuan literasi matematis siswa sehingga pada hasil PISA selanjutnya Indonesia mampu lepas dari deretan penghuni papan bawah dan bisa berada pada deretan bangsabangsa yang maju.

Berdasarkan permasalahan tersebut, penelitian ini berkaitan dengan pengembangan bahan ajar yang berjudul Pengembangan Bahan Ajar Cetak Berbasis Pendekatan Problem Solving untuk Meningkatkan Kemampuan Literasi Matematis pada Siswa SMP.

\section{KAJIAN TEORI}

\section{A. Bahan Ajar}

Bahan ajar adalah segala bentuk bahan yang digunakan untuk membantu guru/ instruktur dalam melaksanakan kegiatan belajar mengajar di kelas (Amri, 2010: 159). Sedangkan menurut National Centre for Competency Based Training (Prastowo, 2011:16), bahan ajar adalah segala bentuk bahan yang digunakan untuk membantu guru atau instruktur dalam melaksanakan proses pembelajaran di kelas. Pandangan-pandangan tersebut juga dilengkapi oleh Pannen (Prastowo, 2011) yang mengungkapkan bahwa bahan ajar adalah bahan-bahan atau materi pelajaran yang disusun secara matematis, yang digunakan guru dan peserta didik dalam proses pembelajaran. Dari beberapa pandangan mengenai pengertian bahan ajar tersebut, dapat dipahami bahwa bahan ajar merupakan segala bahan (baik informasi, alat, maupun teks) yang disusun secara sistematis, yang menampilkan sosok utuh dari kompetensi yang akan dikuasai peserta didik dan digunakan dalam proses pembelajaran dengan tujuan perencanaan dan penelaahan implementasi pembelajaran. Misalnya, buku pelajaran, modul, Handout, LKS, model atau maket, dan sebagainya.

Berdasarkan menurut bentuknya, bahan ajar dibedakan menjadi empat macam, yaitu bahan cetak, bahan ajar dengar, bahan ajar pandang dengar, dan bahan ajar interaktif (Prastowo, 2011).

a. Bahan Cetak (printed), yakni sejumlah bahan yang disiapkan dalam kertas, yang dapat berfungsi untuk keperluan pembelajaran atau penyampaian informasi. Contohnya hand out, buku, modul, lembar kerja siswa, brosur, leaflet, Wallchart, foto atau gambar, dan model atau maket.

b. Bahan ajar dengar atau program audio, yakni semua sistem yang menggunakan sinyal radio secara langsung, yang dapat dimainkan atau didengar oleh seseorang atau sekelompok orang. Contohnya kaset, radio, piringan hitam, dan compact disk audio. 
c. Bahan ajar pandang dengar (audiovisual), yakni segala sesuatu yang memungkinkan sinyal audio dapat dikombinasikan dengan gambar bergerak secara sekuensial. Contohnya, video compact disk dan film.

d. Bahan ajar interaktif (interactive teaching materials), yakni kombinasi dari dua atau lebih media (audio, teks, grafik, gambar, animasi, dan video) yang oleh penggunanya dimanipulasi atau diberi perlakuan untuk mengendalikan suatu perintah dan/ atau perilaku alami dari suatu perintah dan/ atau perilaku alami dari suatu presentasi. Contohnya, compact disk interactive.

\section{B. Bahan Ajar Berbasis Problem Solving}

Istilah problem solving terdapat dalam berbagai profesi dan disiplin ilmu dan memiliki definisi serta makna yang berbeda. Problem solving dalam pembelajaran matematika memiliki arti yang khusus. Menurut Branca (Suherman, 2003) Problem solving adalah proses dimana seorang siswa atau kelompok siswa (cooperative group) menerima tantangan yang berhubungan dengan persoalan matematika dimana penyelesaiannya dan caranya tidak langsung bisa ditentukan dengan mudah dan penyelesaiannya memerlukan ide matematika. Dalam problem solving, biasanya permasalahan-permasalahan tidak tersajikan dalam peristilahan matematika. Seperti apa yang dikatakan Blane dan Evans (Suherman, 2003) Permasalahan yang digunakan dapat diangkat dari permasalahan kehidupan nyata (real life situation) yang pemecahannya memerlukan ide matematika sebagai sebuah alat (tool).

Menurut Polya (Suherman, 2003), solusi soal problem solving atau pemecahan masalah memuat empat langkah fase penyelesaian, yaitu memahami masalah, merencanakan penyelesaian, menyelesaikan masalah sesuai rencana, dan melakukan pengecekan kembali terhadap semua langkah yang telah dikerjakan. Dalam pembelajaran matematika pun siswa harus mengalami pentahapan yang demikian. Oleh karena itu, guru perlu memiliki bahan ajar yang permasalahannya dapat dipecahkan melalui tahap problem solving sehingga mampu meningkatkan kemampuan literasi siswa.

Secara umum bahan ajar dengan pendekatan problem solving adalah bahan ajar yang isi pembelajarannya berbasis pada masalah. Namun, dalam (Retnowati, 2010: 18-20) secara khusus kriteria bahan ajar dengan pendekatan problem solving dipaparkan sebagai berikut:

1. Bahan ajar berorientasi kepada masalah guna memahami konsep matematika

Bahan ajar harus berorientasi terhadap masalah nyata guna meningkatkan pemahaman konsep literasi matematis dengan penjabaran dan pemberian soal berbentuk cerita yang menunjang siswa menggunakan kemampuan analisis dan berpikirnya.

2. Bahan ajar yang dipilih berfokus pada keterkaitan antar disiplin ilmu dengan menggunakan penalaran

Meskipun bahan ajar ini berbasis masalah yang berpusat pada mata pelajaran matematika, tetapi masalah yang dipilih hendaknya benar-benar nyata agar dalam pemecahannya siswa dapat meninjau masalah tersebut dari banyak mata pelajaran atau bidang ilmu.

3. Bahan yang dipilih memberikan bimbingan penyelidikan individual maupun kelompok guna memecahkan masalah 
Bahan ajar ini mengharuskan siswa untuk dapat mengumpulkan informasi yang sesuai guna melakukan suatu eksperimen sehingga mendapatkan penjelasan dan siswa mampu menyelesaikan masalah melalui penjelasan tersebut.

4. Bahan ajar yang dipilih mampu mengembangkan dan menyajikan hasil karya siswa guna mengkomunikasikan gagasan

Bahan ajar ini setidaknya harus dapat mendorong siswa untuk merencanakan dan menyiapkan karya yang sesuai dan membantu siswa untuk berbagi tugas dengan temannya.

5. Bahan ajar yang dipilih mampu menciptakan kerjasama antar siswa agar sikap memiliki sikap menghargai kegunaan matematika

Ciri bahan ajar yang berbasis pada problem solving adalah mampu menciptakan kerja sama antar siswa dalam suatu kelompok. Kerja sama tersebut diperlukan dalam kaitannya dengan sikap menghargai kegunaan matematika.

6. Bahan yang dipilih adalah bahan yang mampu mengorganisasi siswa untuk belajar memahami konsep matematika

Bahan ajar ini memberikan sajian sehingga siswa mampu mendefinisikan dan mengorganisasikan tugas belajar yang berhubungan dengan masalah yang diberikan. Tugas belajar yang dimaksud berkenaan dengan soal-soal latihan.

7. Bahan yang dipilih memberikan kesempatan kepada siswa untuk menganalisis dan mengevaluasi proses pemecahan masalah dengan menggunakan penalaran.

Bahan ajar setidaknya membantu siswa untuk dapat melakukan evaluasi terhadap penyelidikan dan proses-proses yang digunakan oleh siswa dengan menggunakan penalarannya.

\section{Literasi Matematis}

Definisi literasi matematis menurut assessment framework PISA 2009 adalah kapasitas individu dalam mengidentifikasi dan memahami peran matematika dalam kehidupan, untuk membuat penilaian yang dapat dipertanggungjawabkan dan untuk terlibat dalam penggunaan matematika dengan menggunakan kaidah yang mampu memenuhi individu tersebut dalam kehidupannya sebagai warga negara yang maju, peduli, dan piawai berpikir. Berdasarkan definisi tersebut, kompetensi-kompetensi yang dikembangkan melalui literasi matematis memungkinkan siswa untuk memahami, berpartisipasi, dan berkontribusi pada dunia di abad 21 ini. Kompetensi tersebut meliputi kemampuan untuk berpikir, membuat keputusan, memecahkan masalah, mengelola sumber daya, menafsirkan informasi, dan menggunakan teknologi. Dalam Final Draft Mathematical Literacy yang diterbitkan oleh Department: Basic Education Republic of South Africa menyatakan bahwa pengajaran dan pembelajaran literasi matematis harus memberikan kesempatan kepada siswa untuk menganalisis masalah kemudian menemukan cara-cara untuk bekerja matematis dalam memecahkan masalah tersebut. Kesempatan untuk terlibat secara matematis seperti ini juga membantu peserta didik untuk menjadi konsumen cerdik yang tercermin dalam media matematika. Terdapat lima elemen kunci dari literasi matematis, yaitu : 
1. Literasi matematis melibatkan penggunaan konten matematika dasar. Konten matematika pada literasi matematis terbatas pada konsep-konsep matematika dasar dan keterampilan yang relevan untuk membuat skenario numerik dan berbasis statistik dalam kehidupan sehari-hari siswa, serta berpartisipasi sebagai warga negara yang kritis dalam dunia sosial dan politik.

2. Literasi matematis melibatkan konteks kehidupan nyata. Dalam mengeksplorasi dan memecahkan masalah di dunia nyata, peserta didik sangat penting untuk dibuka pemahamannya pada kehidupan sehari-hari yang otentik dan relevan serta lingkungan sosial politik yang global. Sebisa mungkin, peserta didik mampu bekerja dengan masalah kehidupan nyata sebenarnya, bukan dengan masalah sekitar yang dikembangkan, skenario yang semi-nyata dan/ atau fiktif.

3. Literasi matematis melibatkan pemecahan masalah matematika yang akrab dan tidak akrab. Hal ini memang terlihat tidak realistis untuk mengharapkan peserta didik yang berada dalam proses pengajaran literasi matematis selalu terkena semua konteks secara khusus dan relevan dengan kehidupan mereka dan juga terkena pada semua konteks yang mereka temukan di dunia yang akan datang. Seperti yang diketahui, tujuan dari pengajaran literasi matematis adalah untuk membekali peserta didik dengan pengetahuan yang diperlukan dan keterampilan yang didapat untuk memecahkan masalah dalam konteks yang mereka temui dalam kehidupan sehari-hari, terlepas dari apakah konteks secara khusus dan relevan dengan kehidupan mereka atau akrab. Peserta didik dengan literasi matematis harus memiliki kapasitas dan kepercayaan diri untuk menginterpretasikan setiap konteks kehidupan nyata yang mereka hadapi, dan mampu mengidentifikasi, melakukan teknik, perhitungan dan/ atau pertimbangan lain yang diperlukan untuk memahami konteks.

4. Literasi matematis melibatkan pengambilan keputusan dan komunikasi. Seorang individu dengan literasi matematis mampu menimbang-nimbang pilihan dengan membandingkan solusi, membuat keputusan mengenai pilihan yang paling tepat untuk satu set kondisi tertentu dan keputusan berkomunikasi menggunakan terminologi (baik matematika dan nonmatematika) yang sesuai dengan konteks. Oleh karena itu, guru harus memberikan siswa kesempatan untuk mengembangkan dan mempraktekkan proses pengambilan keputusan dan keterampilan komunikasi.

5. Literasi matematis melibatkan penggunaan konten yang terpadu dan/ atau keterampilan dalam memecahkan masalah. Konten, keterampilan, dan konteks dalam dokumen ini disusun dan dikelompokkan sesuai dengan topik. Namun, masalah yang dihadapi dalam konteks sehari-hari tidak pernah terstruktur sesuai dengan topik konten individual. Sebaliknya, pemecahan masalah dalam kehidupan dunia nyata biasanya melibatkan penggunaan konten dan/ atau keterampilan yang ditarik dari berbagai topik, mampu memecahkan masalah yang berbasis di kehidupan nyata, membutuhkan kemampuan untuk mengidentifikasi dan menggunakan berbagai teknik dan keterampilan terpadu dari seluruh berbagai topik konten.

Tingkat literasi matematis siswa di seluruh dunia dapat diketahui dari studi internasional yang dipercaya sebagai instrumen untuk menguji kompetensi global, yaitu PISA dan TIMSS. PISA (Programme for International Student Assessment) 
adalah studi literasi yang bertujuan untuk meneliti secara berkala tentang kemampuan siswa usia 15 tahun dalam membaca (reading literacy), matematika (mathematics literacy), dan sains (scientific literacy). Sedangkan, TIMSS (Trends in International Mathematics and Science Study) adalah studi internasional untuk kelas IV dan VIII dalam bidang matematika dan sains. TIMSS dilaksanakan untuk mengetahui tingkat pencapaian siswa berbagai negara di dunia sekaligus memperoleh informasi yang bermanfaat tentang konteks pendidikan matematika dan sains.

\section{METODOLOGI PENELITIAN}

Metode yang digunakan adalah metode penelitian dan pengembangan (Research and Development). Menurut Sugiyono [4] metode penelitian dan pengembangan (Research and Development) adalah metode penelitian yang digunakan untuk menghasilkan produk tertentu dan menguji keefektivan produk tersebut. Menurut Puslitjaknov menyebutkan bahwa dalam penelitian pengembangan memuat 3 komponen, yaitu: (1) Model pengembangan; (2) Prosedur pengembangan; (3) Uji coba produk. Prosedur penelitian pengembangan yang akan ditempuh merujuk pada prosedur pengembangan yang dilakukan oleh Borg dan Gall yaitu mengembangkan pembelajaran mini (mini course). Namun, mengingat keterbatasan waktu dan biaya maka pada penelitian pengembangan ini hanya dilakukan sebanyak 7 tahap.

Subjek uji coba pada penelitian ini terdiri dari uji ahli dan uji terbatas pengguna produk dalam hal ini siswa. Untuk uji ahli terdiri dari 3 bidang, yaitu ahli matematika, ahli pendidikan dan ahli desain. Uji ahli matematika diharapkan dapat memberikan masukan terkait konsep matematika dan literasi matematis yang dituangkan dalam bahan ajar cetak ini yang berbasis pada pendekatan problem solving. Uji ahli pendidikan yang berperan dalam penilaian bahan ajar ini diharapkan dapat memberikan masukan secara teoritis mengenai pengembangan bahan ajar berbasis pendekatan problem solving untuk meningkatkan kemampuan literasi matematis siswa. Kemudian, uji ahli desain berperan dalam memberikan penilaian terhadap desain dan tampilan bahan ajar secara keseluruhan.

Uji coba produk dalam pengembangan ini dilakukan dalam skala kecil (terbatas). Adapun angket yang diberikan meliputi angket tertutup dan terbuka. Pemilihan sampel subjek uji coba dilakukan dengan cara purposive sampling. Menurut Riduwan [3] Purposive Sampling ialah teknik sampling yang digunakan peneliti jika peneliti mempunyai pertimbangan-pertimbangan tertentu di dalam pengambilan sampelnya atau penentuan sampel untuk tujuan tertentu. Dalam penelitian ini, sampel yang dipilih adalah siswa SMP di Kota Cilegon karena telah mempelajari materi Bangun Datar Segi Empat sebelumnya pada saat pembelajaran biasa dengan menggunakan bahan ajar yang sudah ada.

\section{HASIL DAN PEMBAHASAN}

Produk Bahan Ajar Cetak Berbasis Pendekatan Problem solving yang berintegrasi pada kemampuan Literasi Matematis pada pokok bahasan Bangun Datar Segi Empat untuk siswa SMP kelas VII ini merupakan bahan ajar yang disusun dengan menekankan pada indikator Literasi Matematis melalui penyampaian materi yang berbasis pada pemecahan masalah. Oleh sebab itu, setiap materi dalam bahan ajar ini disajikan dengan sistematis dan berorientasi 
pada kehidupan nyata agar mampu menuntun siswa untuk menyelesaikan permasalahan yang dihadapinya di dunia nyata. Bahan ajar ini pun menampilkan berbagai ilustrasi gambar dari objek dunia nyata menjadi bentuk bangun datar segi empat sehingga mampu memperjelas penyampaian materi serta mengindikasikan bahwa materi tersebut terdapat aplikasinya dalam kehidupan nyata siswa. Adapun latihan soal dan contoh soal yang disajikan dalam bahan ajar ini mengutamakan adanya tipe soal literasi dengan tingkatan level tertentu yang penyelesaiannya berbasis problem solving (pemecahan masalah).

Bahan ajar ini merupakan bahan ajar yang dikembangkan menggunakan pendekatan problem solving. Oleh karena itu, bahan ajar ini berisi materi dan soalsoal berbasis pada masalah. Adapun, secara khusus kriteria bahan ajar dengan pendekatan problem solving dipaparkan sebagai berikut:

1. Bahan ajar berorientasi kepada masalah guna memahami konsep matematika.

Bahan ajar berbasis problem solving adalah bahan ajar yang berorientasi pada masalah yang diselesaikan siswa dengan konsep matematika. Dengan demikian, diharapkan akan tercipta pada diri siswa kemampuan berpikir logis, analisis, pemodelan masalah, dan menarik kesimpulan. Pada bahan ajar ini, khususnya materi bangun datar segi empat, siswa dituntun untuk menghadapi masalah yang konteksnya terdapat di dunia nyata kemudian diarahkan untuk menyelesaikan masalah tersebut dengan langkah-langkah matematis sehingga dapat memahami konsep matematika. Hal ini dapat dilihat pada pada hampir disetiap sub bab, seperti pada gambar di bawah ini.
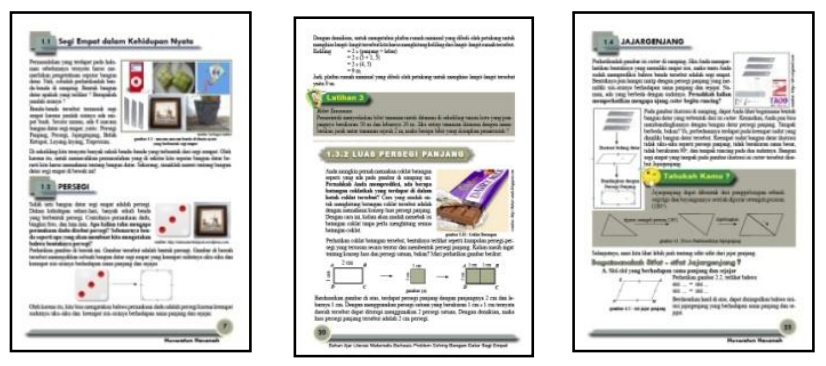

Gambar 1. Beberapa Contoh Penjabaran Materi Berbasis Masalah

2. Bahan ajar berfokus pada keterkaitan antar disiplin ilmu dengan menggunakan penalaran

Penjelasan materi dan penyelesaian masalah dalam bahan ajar ini tidak hanya fokus pada mata pelajaran matematika, tetapi menggunakan penalaran yang berkaitan pada bidang ilmu lainnya yang membuat matematika dapat diterapkan banyak bidang ilmu lain. Hal ini dapat dilihat pada beberapa latihan dan soal yang ada dalam setiap sub materi, seperti pada gambar di bawah ini. 


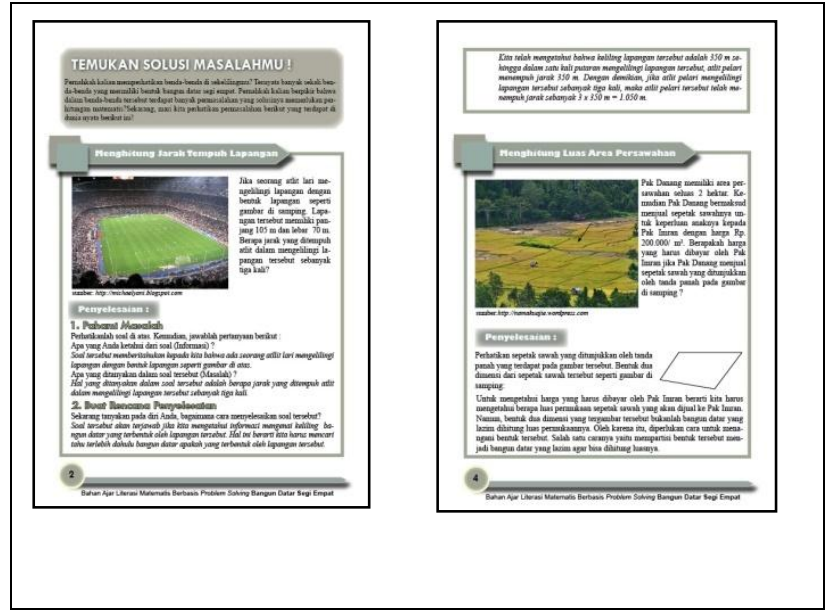

Gambar 2. Keterkaitan Penjelasan Materi dan Soal dengan Disiplin Ilmu Lain

3. Bahan ajar memberikan bimbingan penyelidikan individual maupun kelompok guna memecahkan masalah dan menyajikan hasil karya siswa guna mengkomunikasikan gagasan.

Bahan ajar berbasis problem solving menuntun siswa agar mampu memecahkan masalah secara individu maupun berkelompok. Di dalam bahan ajar ini terdapat sebuah komponen bernama "berpikir kritis". Komponen ini memberikan bimbingan kepada siswa untuk memecahkan masalah sesuai materi yang telah dijelaskan, baik secara individu maupun berkelompok. Kemudian, hasil karya siswa tersebut dijelaskan dengan mengemukakan alasan yang tepat dan logis sesuai materi. Hal ini dapat dilihat pada halaman 9 dan 13.

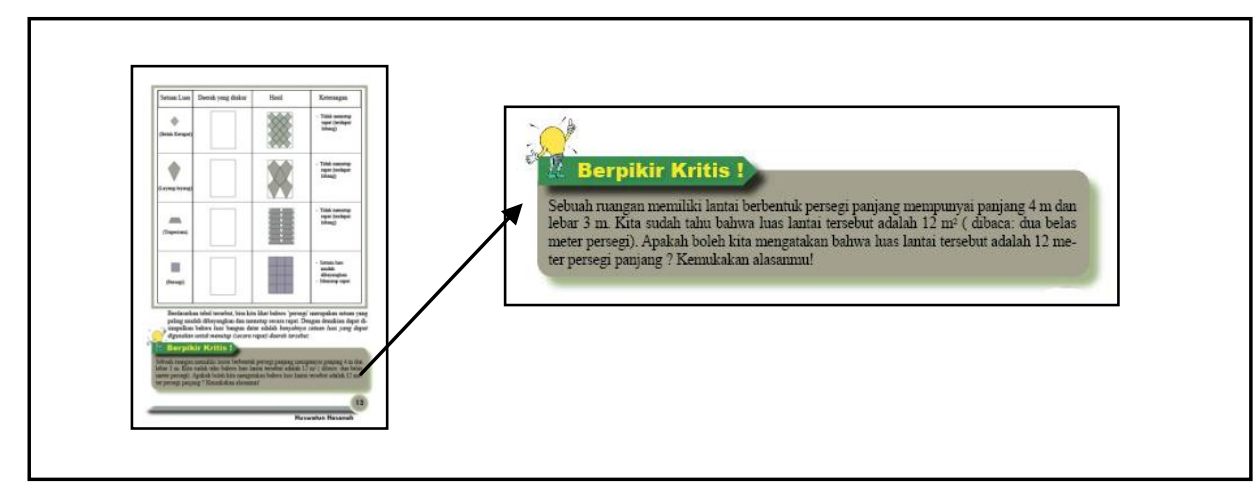

Gambar 3. Salah Satu Komponen Berpikir Kritis

4. Bahan ajar memberikan kesempatan kepada siswa untuk menganalisis dan mengevaluasi proses pemecahan masalah dengan menggunakan penalaran.

Dalam bahan ajar ini, kesempatan siswa untuk menganalisis dan mengevaluasi masalah diberikan dengan menampilkan komponen "analisis masalah". Dengan adanya komponen tersebut, siswa dibimbing untuk bisa menggunakan kemampuan penalarannya dalam menganalisis masalah yang diberikan serta 
mengevaluasi permasalahan tersebut berdasarkan materi. Hal ini dapat dilihat pada halaman 16 dan 27.

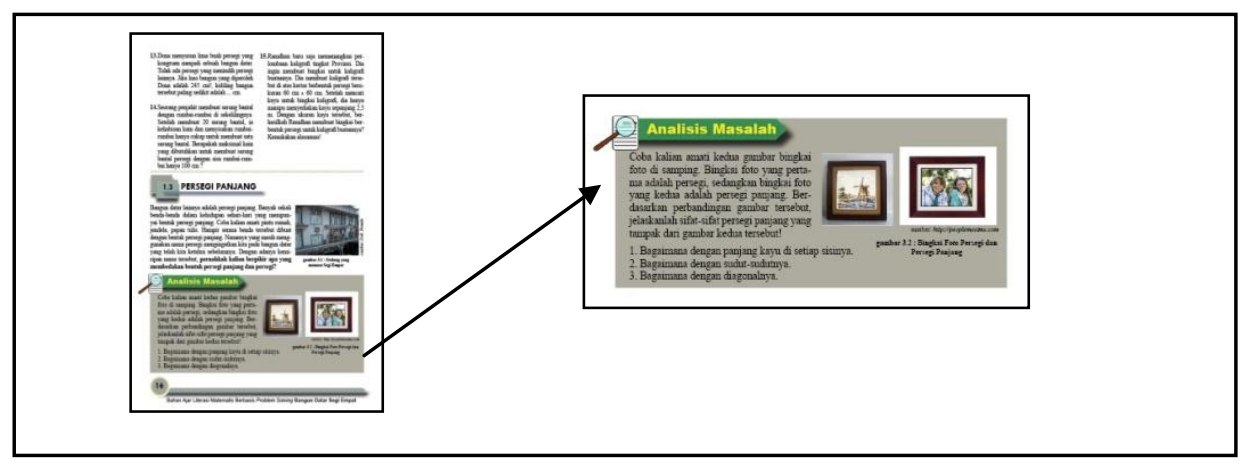

Gambar 4. Salah Satu Komponen Analisis Masalah

5. Bahan ajar yang dikembangkan mampu mengorganisasi siswa untuk belajar memahami konsep matematika.

Bahan ajar ini dikembangkan berawal dari kritisisasi pada kemampuan literasi matematis siswa yang rendah dilihat pada performa mereka di ajang PISA. Oleh karena itu, pada bahan ajar yang dikembangkan oleh pengembang ini telah dibuat menggunakan pendekatan problem solving agar mampu mengorganisasi siswa untuk belajar memahami konsep matematika. Dengan demikian, setiap latihan soal dalam bahan ajar ini dibuat sesuai dengan kriteria soal literasi matematis.

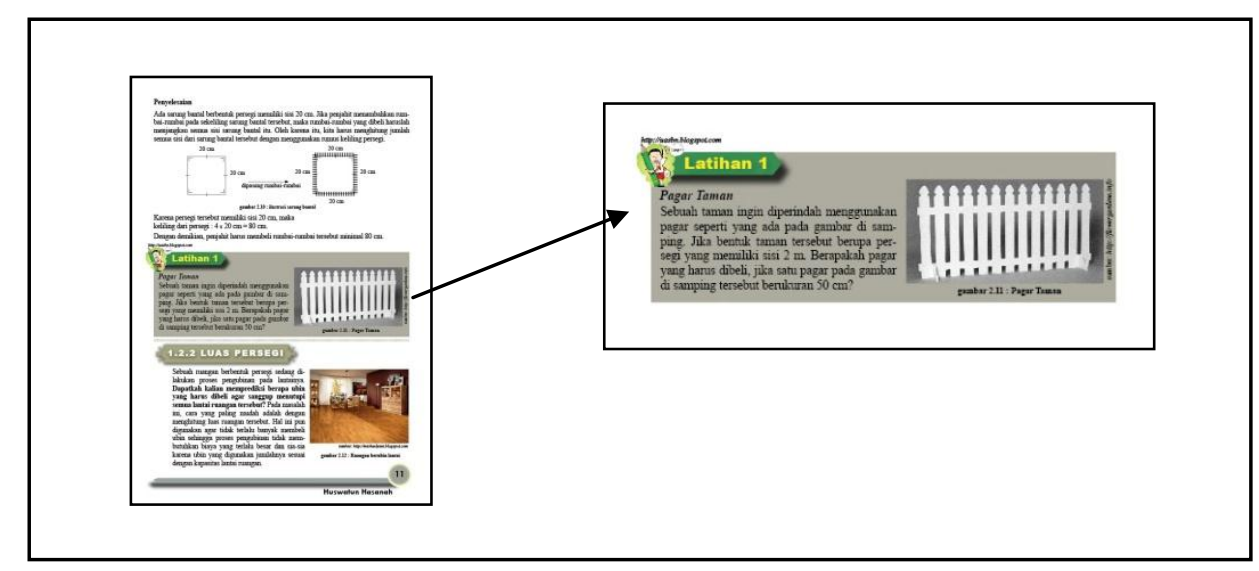

Gambar 5. Salah satu komnonen Latihan Soal

Bahan ajar berbasis problem solving ini dibuat untuk memaksimalkan pembelajaran dan sebagai bahan ajar yang efektif untuk meningkatkan dan melatih kemampuan siswa dalam melakukan analisis permasalahan matematika pada kehidupan keseharian siswa sehingga bermanfaat bagi dunia pendidikan. Berdasarkan penelitian yang telah dilakukan dengan memberikan angket kepada 
para ahli, pengujian materi oleh dua orang ahli matematika memperoleh skor akhir yaitu sebesar $81,05 \%$. Hasil akhir yang diperoleh pengujian oleh dua orang ahli pendidikan dari institusi yang berbeda mendapatkan perolehan skor akhir sebesar $82,67 \%$. Hal yang disoroti pada tahap pengujian ini, tidak hanya unsurunsur yang sifatnya mempermudah siswa dalam memahami isi bahan ajar, namun juga melihat apakah bahan ajar ini mampu menumbuhkan sifat berpikir kritis, kreatif, mendorong rasa ingin tahu siswa dan memberikan tantangan bagi siswa. Pengujian ahli yang terakhir adalah pengujian desain bahan ajar. Adapun hasil yang diperoleh pada pengujian ini yaitu sebesar $74,29 \%$.

Tahapan pengujian yang terakhir adalah melihat respon siswa setelah mendapat dan mencoba menggunakan bahan ajar ini. Pada hasil angket pengujian skala terbatas mendapatkan skor akhir sebesar 83\%. Secara khusus beberapa aspek dalam angket yang merujuk pada peningkatan kemampuan literasi matematis pada siswa telah menunjukan hasil yang positif.

Melalui seluruh perolehan skor yang telah dijabarkan di atas, menunjukan bahwa rata-rata skor berada di atas $60 \%$. Oleh karena itu jika melihat pada keseluruhan hasil yang diperoleh, dan ditunjang melalui pendapat para ahli, bahwa bahan ajar berbasis pendekatan problem solving dapat meningkatkan kemampuan literasi matematis siswa dan menunjukan hasil yang baik.

\section{SIMPULAN DAN SARAN}

Setelah dilakukan berbagai tahap pengembangan pada produk bahan ajar berbasis problem solving ini, pengembang menyimpulkan bahwa merancang suatu bahan ajar cetak berbasis pada pendekatan problem solving untuk meningkatkan kemampuan literasi matematis harus memperhatikan beberapa hal yang penting, terutama terkait isi bahan ajar. Penjelasan materi yang terdapat di dalam bahan ajar ini harus memperhatikan karakteristik problem solving. Ilustrasi gambar dari objek dunia nyata menjadi bentuk bangun datar segi empat menjadi hal yang penting karena mampu memperjelas penyampaian materi serta mengindikasikan bahwa materi tersebut terdapat aplikasinya dalam kehidupan nyata siswa. Kemudian, soal-soal latihan yang dibuat harus mencakup indikator literasi sehingga dapat melatih dan meningkatkan kemampuan literasi matematis siswa.

Dengan demikian, proses pengujian bahan ajar dilakukan oleh uji ahli dilakukan kepada tiga bidang ahli, yaitu uji ahli matematika, uji ahli pendidikan, uji ahli desain serta uji coba terbatas juga dilakukan kepada siswa SMP yang berperan sebagai sasaran utama dari pengembangan bahan ajar berbasis problem solving ini. Skor akhir dari masing-masing pengujian yaitu uji ahli matematika mendapatkan persentase skor akhir sebesar 81, 05\%. Uji ahli pendidikan mendapatkan skor akhir 82, 67\%. Uji ahli desain mendapatkan skor akhir 74, 29\%. Uji skala terbatas mendapatkan skor akhir 83\%. Berdasarkan keseluruhan skor yang telah diperoleh dari proses pengujian tersebut menunjukan bahwa bahan ajar ini sangat baik dan mampu meningkatkan kemampuan literasi matematis siswa SMP.

Berdasarkan kesimpulan yang diperoleh di atas, maka terdapat beberapa saran untuk peneliti lain yang akan mengembangkan bahan ajar cetak berbasis problem solving antara lain bahan ajar yang dikembangkan tidak hanya terbatas pada materi Bangun Datar Segi Empat dan penggunaan bahan ajar yang dilakukan pada proses pembelajaran di luar kelas. 


\section{DAFTAR PUSTAKA}

Kilpatrick, J dkk. 2001. Adding it up: Helping Children Learn Mathematic. Washington DC: National Academic Press.

Pranoto, dkk. 2011. Program Matematika Sekolah Indonesia. Ringkasan Eksekutif. Tidak diterbitkan

Prastowo, A. 2011. Panduan Kreatif Membuat Bahan Ajar Inovatif Menciptakan Metode Pembelajaran Yang Menarik Dan Menyenangkan. Yogyakarta: DIVA Press.

Retnowati, H. (2010). Produk pengembangan bahan ajar berbasis masalah pada materi keliling dan luas segitiga untuk siswa SMP kelas VII. Skripsi tidak diterbitkan. Malang: Universitas Negeri Malang.

Riduwan. 2008. Dasar-Dasar Statistika. Bandung: Alfabeta.

Sugiyono. 2010. Metode Penelitian Pendidikan Pendekatan Kuantitatif, Kualitatif, dan R\&D. Bandung: Alfabeta.

Suherman, dkk. 2003. Strategi Pembelajaran Matematika Kontemporer. Bandung: JICA

Tim Puslitjaknov. 2008. Metode Penelitian Pengembangan. Jakarta : Pusat Penelitian Kebijakan Dan Inovasi Pendidikan Badan Penelitian Dan Pengembangan Departemen Pendidikan Nasional 